Article

\title{
Sustainable Development of Students' Assumed Responsibility for Their Own Learning during Participatory Action Research
}

\author{
Aušra Kazlauskienè ${ }^{1}$, Ramutè Gaučaite ${ }^{1}$, Dolors Cañabate ${ }^{2,3}$, Jordi Colomer ${ }^{3,4, *(D)}$ and Remigijus Bubnys ${ }^{1} \mathbb{D}$ \\ 1 Institute of Education, Vilnius University Siauliai Academy, 76351 Siauliai, Lithuania; \\ ausra.kazlauskiene@sa.vu.lt (A.K.); ramute.gaucaite@sa.vu.lt (R.G.); remigijus.bubnys@sa.vu.lt (R.B.) \\ 2 Department of Specific Didactics, University of Girona, 17004 Girona, Spain; dolors.canyabate@udg.edu \\ 3 Teaching Innovation Networks on Reflective and Cooperative Learning, Institute of Sciences Education, \\ University of Girona, 17003 Girona, Spain \\ 4 Department of Physics, University of Girona, 17003 Girona, Spain \\ * Correspondence: jordi.colomer@udg.edu; Tel.: +34-630-349-766
}

Citation: Kazlauskienè, A.; Gaučaitè, R.; Cañabate, D.; Colomer, J.; Bubnys, R. Sustainable Development of Students' Assumed Responsibility for Their Own Learning during Participatory Action Research. Sustainability 2021, 13, 10183. https:// doi.org/10.3390/su131810183

Academic Editor: Marc A. Rosen

Received: 14 July 2021

Accepted: 10 September 2021

Published: 12 September 2021

Publisher's Note: MDPI stays neutral with regard to jurisdictional claims in published maps and institutional affiliations.

Copyright: (c) 2021 by the authors. Licensee MDPI, Basel, Switzerland. This article is an open access article distributed under the terms and conditions of the Creative Commons Attribution (CC BY) license (https:// creativecommons.org/licenses/by/ $4.0 /)$.

\begin{abstract}
The goal to ensure sustainable development in the education process obliges to create such practices of teaching and learning which would create conditions for individuals to act in complex situations in a sustainable manner. Personalized, perceived responsibility of a learner for one's own learning becomes important for implementation of sustainable learning. This research is aimed to reveal authentic experiences of school students assuming responsibility for learning, emphasizing prospects of sustainable education development in practice and possibilities for improvement by employing the strategy of participatory action research. The data was collected according to the stages of the chosen action research during lessons on learning to learn. Forty-six school students and two teachers took part in the research. On the basis of content analysis, it was revealed that school students assume the responsibility for learning when it is grounded on cooperation taking place in the dialogue-based culture, where negotiation and creation of opportunities to choose are among the most important strategies making the assumed responsibility relevant. Intervening conditions emerging in the context of the strategies were also identified: making learning experiences relevant, clarity of criteria, attitude towards failure and the self as a major resource of learning, expectations, and goals and feedback of learning. Interacting with each other, prevailing strategies, and intervening conditions act as components of sustainable development of school students' assumed responsibility for learning.
\end{abstract}

Keywords: sustainability; responsibility for own learning; cooperation; participatory action research; learning diversity; diversity

\section{Introduction}

The basis of the sustainable development conception is laid on pursuit of public welfare based on constructive interaction among environment, economy, and society. The goals and associated objectives of sustainable development are integral and undivided; therefore, attention to some of the goals makes an effect on the quality of implementation of other ones [1]; thus, this means public welfare, too. Significance of education in the development of public welfare is being made relevant while singling it out as a separate goal of the concept of Sustainable Development education: to "ensure inclusive and equitable quality education and promote lifelong learning opportunities for all" [2]. Research studies demonstrate that human life prospects strongly depend on education: more educated people are healthier, live longer [3], their children have higher aspirations and goals in education and life, education means person's possibilities to enter a higher social stratum, etc. [4]. Therefore, skills of self-directed learning become the skills that ensure an opportunity to continuously change in line with a changing environment while perceiving the self as an inseparable part of global issues and engaging in co-creation of sustainable society to 
solve them [5]. Personalized, perceived learner's responsibility for own learning becomes important for implementation of such learning, which is inseparable from creation and directing of one's own learning [6].

Responsibility is linked to intrinsic commitment of a learner to seek set results while choosing particular strategies to achieve that goal. Following the theoretical provisions of social constructivism, teaching and learning is created through person's active performance in the contexts of relationships with others [7-9]. Therefore, seeking learning goals through collaboration with others, tensions of various types occur due to differences (ways, forms of cognition, thinking, learning, etc.) in high diversity of school students that cause learning barriers, bullying, and initiation of discrimination [10] among the learners. When dealing with non-discrimination, usually investigation is focused on assurance of equal opportunities in the aspects of gender, social status, financial status, language, etc. [11]. Experiences of the occurrence of bullying as discriminative behavior, including those arising from differences in learning $[10,12]$ may have a negative effect on continuous personal development, influence not only attainments, but also success in further life.

Diversity in successful systems of education is treated as a source of potential growth and not as an obstacle to achieve students' learning outcomes [13]. In the context of the point of view towards other peers, learner's responsibility assumed for learning helps to understand that different achievements in learning are not "a natural talent", but a result of intensive learning endeavors depending on efforts of a learner. School students who experience their learning as that of an authoritative creator of reality obtain skills which allow further consideration of learning as a constructive process through their own authentic attempts, experienced success and mistakes. Moreover, when learning together and sharing their insights, they have an opportunity to discover the connections (consolidating statements) of their authentic learning experiences which gradually become regularities of their process of learning. Investigation of one's own learning experience (meta-learning) renders an understanding of learning outcomes which can be achieved in very different ways and that they can be interesting to all students. This alters value orientations and attitudes towards other peers, and helps to avoid extreme marginalization and bullying due to learning differences.

Thus, schools must put much effort to recognize the diversity of students' learning needs, goals, possibilities, and ways to achieve these goals. When coping with inequality, it is important to recognize differences in students' learning not as a stigmatizing drawback, but as an advantage allowing construction of a specific, individual path of leaning through interaction with others, emphasizing importance of efforts and assumed responsibility associated with individual achievements. From the learner's perspective, teachers may assist learners to become responsible for their learning. For this purpose, it is important to focus on actions of both students and teacher that create conditions for students to see their own learning as a meaningful activity [14] and, through joint performance and gradual transfer of responsibilities to learners, to encourage them to become owners of their own learning [15]. This is also a process where pedagogue's major role is to make this process easier while facing many challenges in the course of education in practice.

The recognition of students' ability to assume responsibility for their learning may be a powerful tool in pursuit of attainments and advancement [16]. Due to emphasized accountability for students' academic achievements, teachers still have difficulties in creating conditions that support students' responsibility for their own learning. The said responsibility conditions teacher's domination in classroom and manifestation and consequences of reproductive learning, which obstruct the transferring of responsibility for learning to actual learners, and this is far from the requirements set for contemporary education. Therefore, efforts should be put in practice to create specific conditions for teaching and learning to allow revealing the students' learning as a process to form the processual perception of learning as a continuous process in the time frame which requires efforts of the actual learner to achieve the goal and assume responsibilities for the outcome. Only the process of learning which is visible to both teacher and learner can be meaningful [14] 
and construct the understanding of how some kind of result is obtained; it also helps to become aware of authenticity of own and others' learning.

This research is aimed to reveal authentic experiences of school students assuming responsibility for learning, emphasizing prospects of sustainable education development in practice and possibilities for improvement by employing the strategy of participatory action research (as democratic philosophy of knowledge production encouraging creation of shared knowledge).

Meeting the said ideas, the conducted research creates conditions for emphasizing authentic experiences of manifestation of students' responsibility for learning as well as education prospects, which renders insights about possibilities for sustainable development of students' assumed responsibility for their learning.

\section{Prospects of Sustainable Development of Students' Assumed Responsibility for Their Learning}

The construction of teaching and learning is based on the belief that learning proceeds when learners actively participate in the process of construction of meaning and knowledge, and not when information is obtained in a passive way. Learners are creators of meaning and knowledge [17-20]. Maintaining the position that teaching and learning are a social, cultural process being created through personal activity and relations [7,21], it can be admitted that the sociocultural context is not only a place for learning. The sociocultural context has effect on how individuals learn (taking part in cultural activities) and what they learn (social practice), and this is part of what is learnt [22]. This means that participation in social interaction creates conditions for meaningful learning [9]. Therefore, in a classroom environment, students must experience the event to make it meaningful, when teachers hold a less defined and less official role in comparison to those in traditional classes (instructor, assistant, supporter, consultant) [23,24]. With teachers accepting this new role, the school environment should create conditions for students to express their opinions and substantiate their attitudes as well as to demonstrate their respect for opinions of others. Thus, they become acknowledged as members of the co-creation process with students' assuming responsibility for their own learning [25].

With rethinking contemporary education discourse, a shift is observed of the approach from education as service to education as social interaction based on equal, autonomous relationships $[7,21,22]$. From the viewpoint of social constructivism, social interaction is presented as a stimulus for growth and development of cognition [26]. Research studies demonstrate that motivation for learning and attainments depend on relationships $[8,27,28]$. Education is more often perceived as an exchange of experiences: we gain knowledge, render it, exchange it, i.e., we interact while communicating, collaborating, coming up with an agreement, and sharing. Therefore, a teacher is no longer treated as a provider of high-quality service of teaching and a student as a passive receiver of that service. Learning does not proceed against the learner's will or as a teacher's willful action; a dialogue and negotiation with all interested parties is the fundament of learning. Interaction taking place in such culture supports the idea of lifelong learning because authentic experience of teaching and learning being constructed in its context is significant to a student, the parents or caregivers, and a teacher.

Maintaining this approach to learning, sustainable conditions, strategies that provide conditions for students' assuming responsibility for learning, are being pointed out. According to Belenky et al. [29], Boomer [30], and Cook [31], responsibility can be perceived when in the culture of an authentic dialogue, it is assumed voluntarily through collaboration with others, when discussion of all interested individuals allows to produce independent deliberate decisions and choices that are important to one's own and others' learning. This is the process of co-creation; the construction of it highlights the importance of the processual approach to learning [32].

Scientific literature reveals the diversity of conceptual approaches to construction of own teaching and learning as well as responsibility for this; some most important ones are presented as follows (Figure 1). 


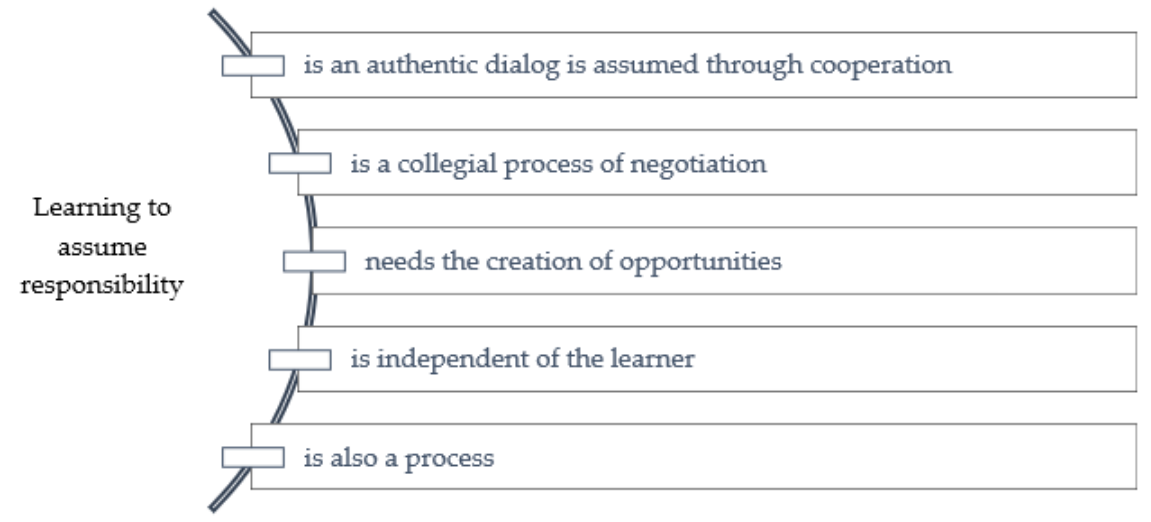

Figure 1. Conceptual approaches to the learning to assume responsibility for own learning.

Learning to assume responsibility as an authentic dialogue is assumed through cooperation. Scholars consider that not only knowledge encourages students to learn, but rather the search for understanding [33], which in many cases takes place in the course of development of a dialogue through interaction with others. This means that such practice of learning is produced when students interact with individuals holding the same (e.g., peers) or different social status (e.g., teacher) jointly seeking personal learning goals [34]. Despite that, when the interaction proceeds through communication or cooperation with others, the interaction is based on an authentic dialogue because such process is required by each person's authentic perception. A dialogue between school students, teachers and learners, society and individuals, between what a student knows and understands, and what one needs to know and understand, not only expresses authentic thinking, but also structures it, and forms processes required for learning that proceeds or should proceed at school [35-38].

Chin, Donnell, Jinks [39] found out that students actively discuss when they talk about particular tasks and their implementation, when they must substantiate their choices, and decisions are made. This encompasses processual actions that are important to independent learning and, thus, responsibility, such as listening to asked questions, viewpoint of another person, explanation of own viewpoint, development of ideas, arguing grounding one's viewpoint, making decisions, etc., maintaining respect to manifestation of differentness. Veenman et al. [40] point out that purposeful learning of actions has a positive effect on students' thinking, considerations and learning attainments. Belenky et al. [29] explain that there is no dominance in the "true dialogue" and reciprocity, and that cooperation is to be learned [41].

Scholars [42,43] emphasize the importance of a teacher's role when creating conditions for reciprocal cooperation. They observe that it is important not only for school students to understand how to listen, question, assist, explain, and come up with an agreement in activities of small groups, but also to model this behavior when teachers appropriately communicate with their students. Thus, success of cooperation strongly depends on the conditions provided by a teacher. Manifestation of a teacher's role is focused on creation of a classroom as a cooperating community, accumulation of common practice for the sake of better understanding, and ensuring opportunities for students to gradually seek learning goals and reveal their understanding being formed.

Learning to assume responsibility is a collegial process of negotiation. In the course of construction of students' learning, as Boomer [30] points out, negotiation is an important aspect. It brings together the negotiating sides for a common purpose. Boomer [30] provides a comment on the essence of collegial negotiation about teaching and learning: negotiation means deliberate planning to invite students to contribute to the process of learning so that they could understand the purpose not only for the sake of process but also for the sake of a result. Cook [31] emphasizes that collegial negotiation among actors of learning creates conditions to experience that learners will work harder and more effectively, because what 
has been learnt will mean more to them or will be more important as they discover their ideas, ask their questions, and become more engaged because they want to answer these questions themselves. A sense of students' responsibility for work must be accomplished and occurs from agreements; thus, it is also a commitment. It can be stated that negotiation is the action which renders learners an opportunity to participate in making decisions that are important to their learning, and, thus, assuming of responsibility for own learning. All of these demand that teachers must construct such educational conditions [44].

Learning to assume responsibility needs the creation of opportunities. The approach to learning being managed/constructed by a learner himself/herself creates conditions for a teacher to expand the opportunities for students' leaning through making choices [17]. A teacher, rejecting regular practice to tell students what to do and in what order, enhances their self-confidence and opens opportunities for them to participate in the process of construction/creation of their learning, and, thus, decision-making concerning their learning. Active involvement of students into their learning is important when constructing learning and the meaning of learning. This means that the process is uncontrolled: students are given many opportunities to choose; however, they all are directed to pursuit of the set outcome. A paradox of such "restricted freedom" is underlined by Sheridan [45] who comments on substantiation of the use of structure when teaching students to make choices and assume responsibility for them. A structure is one of the conditions for freedom (if students are not given parameters of behavior, acting, etc., nothing is achieved because they are not aware of what they are expected of and what they should actually do). The paradox lies in a situation where the more control is given to school students, the less concern about that control appears to a teacher because students are able to supervise themselves and, even more, take care of each other. In such conditions, control appears due to the assumed students' responsibility and not due to externally superimposed measures, giving teacher a possibility to focus on student learning. In such a way, conditions for a learner to be independent are provided.

Learning to assume responsibility is independent of the learner. The independence of a learner can be basically defined as the taking of control for own learning and responsibility for learning in own hands. Benson [46] considers that control or responsibility may be of different forms related to different levels of the process of learning. Since students independence is a major goal of the teaching being constructed, the shift of the power structure in a classroom is a desired action [17]. Fundamentals of enabling students for independence may be laid by encouraging students to ask questions and turning them into active students. Calkins [47] considers that asking questions is a complex and important part of thinking and learning. Having asked questions, students gain more awareness and control on their thinking. According to Grey [17], a learner who has questions achieves not only the answers but also the power. Students can assume more responsibility when a teacher gives more autonomy to them to choose and make decisions. A teacher enables students by engaging them, rendering them responsibility and encouraging them to selfcontrolling and to learn how to be independent individuals.

Learning to assume responsibility is also a process. When constructing the process of teaching and learning, a processual approach is emphasized because it is a highly important aspect in students' subject-related attainments and longevity of learnt knowledge [32,48,49]. This does not mean that the result is not important. This means that if we "lose" the process, we "lose" the result, too [50]. Thus, Mohammed, Kinyo [9] emphasize that, in learning, it is very important to create conditions for active participation in the process of learning, and to manage it because this is the only way to create new models of knowledge. In such a context, learners feel like participating in co-creation of the process of learning. Whalen [51] emphasizes that they critically consider their learning according to how strongly it allows/restricts the approaching to the goal of learning and feel responsibility for controlling it. Therefore, grounding on Darling-Hammond, Flook, Cook-Harvey, Barron and Osher [52], teachers should put efforts to ensure social communication of students coming up with an agreement about perception and facts instead of testing whether their 
students simply memorized knowledge from textbooks. In such activity, goal/objective setting for education is the first thing a teacher should do [17].

\section{Research Methodology}

\subsection{Research Context and Participants}

The research was carried out having chosen one unique and particular case of a comprehensive education school in Lithuania. To choose the school, purposive sampling was applied with regard to the instance that this comprehensive education school was included in the list of best schools at the national level according to students' learning attainments and, having won the selection, it had a possibility to independently improve the quality of the education process. Exactly in this school, seeking quality of the education process, the curriculum for the 5th form students (aged 11-12 years) included a lesson on learning to learn, which provided conditions for the implementation of the action research strategy. In its mission, the school emphasizes that they are continuously learning, cooperating, and educating responsible personalities seeking for continuous advancement. Responsibility is one of the values of the school. In the year (2019-2020 academic year) when the action research was being conducted, the curriculum for form 5 (students aged 11-12 years) included a lesson on knowing how to learn (six months, for a total of 24 lessons). The action research took place during lessons on knowing how to learn. Two fifth forms (46 school students) and two teachers who conducted lessons on knowing how to learn to students took part in the investigation.

\subsection{Research Strategy and Design}

The research was conducted by applying the participatory action research. Seeking sustainability recognizing democratic practice, researchers chose the way to demonstrate respect to children, and considered the knowledge being created by them as an experience which they brought into the process of investigation; that is, they searched for the manifestation of democratic processes seeking changes in leaning and commitment to act [53] (students could express their experiences and needs, and put to action ideas creatively and in ways that are significant to culture).

This type of action research was chosen also because changes were established in both processes and results [54]. The said type of action research supposed the selection of the four-step model (see Figure 2) [55]. It provides conditions to reflect according to a cyclic character of the action research. This iterative process evolves through a spiral of planning, acting and observation, revised planning, and further implementation of self-reflection, which took two cycles.
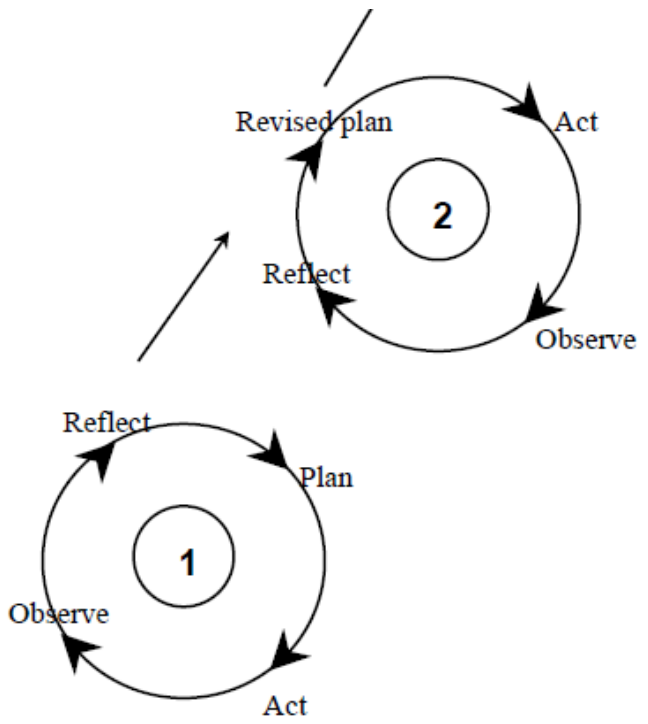

Figure 2. Model of action research, based on Kemmis, McTaggart [55]. 
Cycle One

At the beginning of the cycle one, the focus was on:

- Understanding of the context: for this purpose, teachers' reflections, non-formal conversations with school students were used.

- Enhancement of commitment to school and interested people: when negotiating, a commitment was made to share generalized research results and interactive games with school students identifying their needs.

During the entire process, a journal that recorded researchers' memos and considerations was created.

During the planning step, before the initial cycle of action research, a group discussion was arranged [55]; its purpose was to give importance to assumed students' responsibilities for their learning and understanding of the limits of own responsibility for learning, and negotiate with students what to start with when learning to set own learning goals. For this purpose, interactive methods of visualization were employed to find out the approaches to setting learning goals, i.e., to understand what experiences of setting learning goals and preferences of goals dominate, how successfully these goals are being implemented, and how children see themselves on the way to implement these goals. As there were 23 students in the classroom, seeking that all could actively engage and be heard, in this stage we arranged 6 discussions including 4 students. The second and third group discussions were held at the end of cycles 1 and 2, respectively, when experiences gained by students were generalized and prospects of changes were emphasized as relevant. In order to engage all students, we used various creative methods evoking discussions during group discussions (concept mapping, drawing, play, etc.) [56].

During the initial stage of action, students were learning to set goals related to learning while cooperating in classroom. The purpose of such activity is to provide conditions for students to test methods for learning goal setting, to select the most suitable ones for them, and to master these methods. Later, students had to transfer the gained experience to an individual level, when they put their abilities to action by setting learning goals for all taught subjects. They recorded the process of this activity, including the experiences in performing the reflection narratives.

By applying the method of observation, teachers observed activities and noted them in a journal. Observation of participants was used for collection of information, especially on learners creating conditions for taking actions. The field observation data was used as a basis for further report on observation. Thus, in order to collect examples of students' experiences and illustrate their actions, the critical incident technique applied in the course of observation was employed [57].

In generalization stages in all cycles, as mentioned, group discussions were arranged while applying creative methods. In each stage, six group discussions including four students in each were held. Grounding on them, decisions were made for further process of learning. In this case, decisions regarding actions of a student as a learner when setting learning goals and correction of teacher's role.

Cycle Two

During the stage of revision of the plan, initiatives were directed to actions of a student as a learner and corrections of teacher's role: revision of the process of learning goal setting and foreseeing implementation of it.

All this was tested during the activity stage, i.e., instructions agreed on the basis of students' and teachers' suggestions and chosen approaches for implementation of the learning goal were transferred to a practical level (the backward design was applied for implementation of the goal: success criteria are foreseen; on the basis of them, selfassessment of own experiences proceeds by providing constructive arguments; actions that will be taken to alter the situation are foreseen and recorded; and selection of actions is based on strengths of one's personality). Throughout the entire process, they reflected their experiences and teacher's actions while recording them in reflection sheets. Teachers observed the activity and made notes in the journal, similar to the first stage. 
This generalizing stage ended with consideration of the participants taking part in group discussion and dissemination. Students considered their experiences (while performing mind mapping) and introduced them to peer students attending the fifth form who did not participate in the action research, to parents, and to the school community in order to consolidate their skills, and to encourage other teachers to apply the technique that was used. All cycles lasted for 6 months.

\subsection{Data Analysis}

Grounding on content analysis (making relevant data collected both from students and teachers), it was aimed to systematically identify the conditions for assuming responsibility for learning by students [58]; the following coding procedures were performed: open coding and axial coding [59]. An example of conceptualization of open coding is presented in Table 1.

Table 1. Example of conceptualization of open coding.

\begin{tabular}{|c|c|c|c|}
\hline Fragment of Interview & Label (In Vivo) & Subcategory & Category \\
\hline $\begin{array}{l}\text { "<e.g., Why to sweat if it is possible to adjust. When } \\
\text { you suggest something, you remain guilty or are } \\
\text { forced to do that job. If you see that others don't } \\
\text { want, you don't show your initiative>" C-1 }\end{array}$ & $\begin{array}{l}\text { ". . to adjust. And I do not } \\
\text { show initiative ..." }\end{array}$ & Collegial negotiation & \\
\hline $\begin{array}{l}\text { "in order to solve the occurred problem or situation, } \\
\text { one should try to look at that situation in a different } \\
\text { way. I started more deeply exploring a student as a } \\
\text { person, trying to understand why one learner } \\
\text { behaves in one or another way. At work, I started } \\
\text { more deeply exploring a student, one's emotional } \\
\text { state, wellbeing, encouraging deeply exploring the } \\
\text { self, learn to know the self, recognize occurring } \\
\text { problems and search for ways to cope with } \\
\text { them." A-1 }\end{array}$ & $\begin{array}{l}\text { "... to more deeply explore } \\
\text { a student as a person ... to } \\
\text { know the self" }\end{array}$ & $\begin{array}{l}\text { Creation of opportunities } \\
\text { to choose }\end{array}$ & Cooperation \\
\hline
\end{tabular}

During axial coding, the focus was laid on the analysis of single categories, merging subcategories, regarding the features and dimensions that stand out as strategies and intervening conditions.

The data obtained by applying the critical incident technique were analyzed by grouping and described so that it could be possible to use them to solve problems with regard to a theoretical system related to observed environment and goals of observation [57].

\subsection{Quality Assurance}

Seeking to ensure authenticity of the investigation as research quality, approaches by scholars $[60,61]$ that emphasize that research results are correct and reliable if they are recognizable as authentic by research participants were referred to $[55,62]$. Research quality assurance was aimed at by [60,61]:

- Real problem oriented to practice (perfection of practice is focused on progress in student learning being ensured by conditions created by a teacher for students to assume responsibility).

- Participation and cooperation of all interested parties (all students and a teacher, i.e., those who will be affected by the results of the research, took part in the investigation). Mutual cooperation proceeded at all stages of the investigation: when identifying the problem, making decisions that will change practice, approving data analysis for all interested parties, etc.

- Use of data sources in several time frames and analysis of conclusions in several time frames increased confidence in reliability of conclusions. (Since it was aimed to deeply 
perceive the understanding of the problem, it was important to set a strict process of repeated data collection, consideration, and analysis with individuals and groups).

- Clear focus on a reflective process (both at the beginning of a new activity and reflective discussion at the end, keeping of systematic reflective journal ensured orientation of the process toward reflectivity and provided conditions for all participants to learn from experience).

- Critical and self-critical viewpoint (semi-structured reflection sheets, researchers' memos created conditions to view the process from various angles).

- Provision of all evidences (evidences were presented by using various perspectives: personal opinions and feedback from all participants and interested subjects, various methods, e.g., reflective journals, interview, observation).

- Connections between applied prospects of problem identification and methods of data collection are ensured (perspective of social constructivism is applied directed toward the process of learning ensured possibilities to reveal conditions created by a teacher for a student to assume responsibility for one's learning).

- Aimed at systematic changes in the following aspects: for oneself (as a teacher, as school students) and others (other teachers can use the research results: when recognizing approaches that proved to be useful in their practice or taking ideas of good practice and re-constructing them in their own practice).

- Seeking internalization of theory and practice (the approach stating that theory and practice are two interdependent and mutually supplementing stages of the process of change was maintained. During the discussion, reflection proceeds on how theory defining conditions for students to assume responsibility for their learning manifests in practice and how practice points out conditional elements that supplement theoretical insights).

- $\quad$ Research ethics is ensured (characterized in greater detail in the next section).

\subsection{Research Ethics}

In the present research, research ethics was implemented at three levels: macro, meso, and micro. At the macro level, the following major values were referred to [63]:

- Respect to a person, his/her experience and knowledge brought to the research process;

- Belief in democratic processes ad power of them to achieve positive social changes;

- Commitment to act.

At the meso level, the authors grounded on the following principles [64]:

- Anonymity (information on the participants was protected to prevent connect it with specific data. The data was coded);

- $\quad$ Privacy (private information was not made public);

- Confidentiality (obtained information was handled only in ways that were agreed with all interested parties. This is a commitment to respect);

- Justice (all interested parties (teachers, students) who share power and resources take part in the research seeking benefit to all participants. Consent was obtained from parents in compliance with national and institutional requirements.).

At the micro level, manifestation of the principles was oriented to ethics in action and ethics for action. Ethics in action [65] was set and defined through the stance of shared values (Table 2).

Since the processes in the conducted action research are developing and changing in the processes of action and reflection cycles, all ethical solutions could not be predicted in advance. However, researchers aimed at pointing out major ethical norms that they followed in the action research (ethics for action) [66,67]:

- Grounded on guidelines set in advance that directly regard relations with those who participate in research and those who may be affected by the research;

- Ethical approach was applied in all stages of action research to help all interested individuals to make decisions; 
- Researchers oriented towards making the research process and result clear and transparent to a broader public.

Table 2. Setting structured reflection on research ethics in action.

\begin{tabular}{|c|c|c|c|c|c|c|c|}
\hline Values & $\begin{array}{l}\text { Developing } \\
\text { Partnerships }\end{array}$ & $\begin{array}{c}\text { Constructing } \\
\text { Research Question }\end{array}$ & $\begin{array}{l}\text { Planning } \\
\text { Action }\end{array}$ & $\begin{array}{c}\text { Collecting } \\
\text { Data }\end{array}$ & $\begin{array}{l}\text { Analyzing } \\
\text { Data }\end{array}$ & $\begin{array}{l}\text { Member } \\
\text { Checking }\end{array}$ & $\begin{array}{l}\text { Going } \\
\text { Public }\end{array}$ \\
\hline caring & $x$ & & $x$ & $x$ & $x$ & & $x$ \\
\hline fairness & & & & & $\mathrm{x}$ & & \\
\hline commitment & & & & & & $x$ & $\mathrm{x}$ \\
\hline collegiality & $x$ & $\mathrm{x}$ & & & & & \\
\hline honesty & & & & $x$ & & & \\
\hline inclusiveness & & & $\mathrm{x}$ & & & & \\
\hline openness & & & & & & $x$ & \\
\hline
\end{tabular}

\section{Results}

\subsection{Conditions for the Students to Assume Responsibility for Their Learning}

Cooperation was highlighted as a major condition to assume responsibility for students for their learning. Besides the manifestation of other elements of responsibility for their learning while cooperating as strategies, collegial negotiation and creation of opportunities to choose were the noticeable ones (Table 3).

Table 3. Manifestation of cooperation as learning to assume responsibility when applying strategies of collegial negotiation and creation of opportunities to choose.

\begin{tabular}{|c|c|c|}
\hline Category & Subcategory & Illustrating Statements \\
\hline \multirow[t]{2}{*}{ Cooperation } & Collegial negotiation & $\begin{array}{l}<\text { when they hear my voice, I participate more actively }>;<\text { I wish to continue like } \\
\text { this-looking at us as having knowledge }>;<\text { I see that my ideas, answers on how I } \\
\text { feel are cared for }>\text {; }<\text { I was even surprised when asked my opinion, negotiated for } \\
\text { the first time because usually the teacher herself would do everything }>;<\text { I feel } \\
\text { good when I am asked and I know that they will be glad about my activeness }>\text {; } \\
<\text { now we exchange opinions, make a joint decision. It is better to learn like this. }>\text {; } \\
<\text { earlier, a teacher asked to suggest own ideas, and now I often suggest myself }>;<\mathrm{I} \\
\text { try more to do something when I know that my suggestion is important to all }>\text {; } \\
<\text { and the result improved a little bit. Perhaps because I could ask many questions. } \\
\text { I wanted to answer the questions even more. I didn't want to do that earlier }>;<\text { the } \\
\text { teacher writes our suggestions next to her ones, too. She wants that sometimes } \\
\text { there were more our suggestions that her. Even though it is hard to work, but I } \\
\text { don't want to be lazy. Because that was my suggestion, after all. How others will } \\
\text { treat it. }>\text {; }<\text { when they listen to my opinion, I try to complete the tasks till the end }>\end{array}$ \\
\hline & $\begin{array}{c}\text { Creation of opportunities } \\
\text { to choose }\end{array}$ & $\begin{array}{l}<\text { initially, I did not like choosing because the work must be done }>;<I \text { tried not to } \\
\text { choose, waited until I was told to do. Bet we agreed that I will need to try }>\text {; }<\text { if I } \\
\text { have chosen, there is no way back }>\text {; }<\text { I started being more self-confident when I } \\
\text { decide in what way I will complete the task }>;<\text { now I understand that I have my } \\
\text { own way, what to after what. It does not suit me what suits, for example, my } \\
\text { friend }>\text {; }<\text { when I choose myself, I try more to complete that work. It is funny, but } \\
\text { there is no one to blame then }>\text {; }<\text { sometimes it is difficult to choose what would } \\
\text { you want, you search for an easier option. The teacher noticed that I behaved in } \\
\text { such a way and started negotiating with me, whether I would like to try solving } \\
\text { more complex problems }>\end{array}$ \\
\hline
\end{tabular}

It can be stated that when constructing student engagement in assuming responsibility for learning, strategies of collegial negotiation and creation of opportunities to choose manifest in the process of reciprocal cooperation of students and between teacher and 
students. First, manifestation of cooperation when negotiating with students allowed to feel that teachers care about them, both as learners and persons in general $(<\mathrm{I}$ see that my ideas, answers about how I feel are cared for $>$; $<$ I feel good when I am asked and I know that they will be glad about my activeness $>;<$ I wish to continue like this-looking at us as having knowledge $>;<$ I was even surprised when asked my opinion, negotiated for the first time because usually the teacher herself would do everything). This activates them to engage in their own learning processes, feel responsible for their actions: $(<$ the teacher writes our suggestions next to her ones, too. She wants that sometimes there were more our suggestions that her. Even though it is hard to work, but I don't want to be lazy. Because that was my suggestion, after all. How others will treat it. $>$; $<$ when they listen to my opinion, I try to complete the tasks till the end $>$ ).

Manifestation of cooperation when collegially negotiating was especially highlighted when providing support to each other, scaffolding learning ( $<$ I explain why friends' answer is correct. In such a way, I learn more myself, too $>$; <when friends explain, I somehow understand faster. But when the teacher explains, I often pretend that I understand, but actually I do not $>$; <at the beginning, students would tell the right answer to each other, would not explain $>$; <it suits me when the friend gives me a cue on how to do the task and not solves everything for me $>$ ). It is useful for both those students who provide support and those who receive it. Encouragement of students to help peers learn, created conditions for assuming responsibility for own learning.

The presented thoughts of students suggest that, besides the collegial negotiation strategy, the strategy of creation of opportunities to choose was highlighted as significant to student learning: (<we exchange opinions now, make a joint decision. It better for me to learn this way>). These both strategies acting in the context of cooperation manifested in practice as reciprocally interacting: (<we negotiate what to choose for learning $>$; $<$ when I choose, I want to negotiate . . > ; < after negotiation, it is easier to decide what I will choose $>$ ).

A possibility for students to make choices allows them to live experiences of different learning which extends their understanding about all individuals learning in different ways; different experiences of others may also be significant to their own understanding about learning. A more detailed cognition of own learning contributes with more opportunities to choose, and increases self-confidence in both own powers of learning and oneself in general: (<now I understand that I have my own way, what to after what. It does not suit me what suits, for example, my friend $>$; $<$ I started being more self-confident when I decide in what way I will complete the task $>$ ).

Moreover, while negotiating and grounding choices, students understand that learning attainments depend on their efforts, that the choice made becomes a particular commitment to assume responsibility for own actions and this activates them to act (<if I have chosen, there is no way back $>$; $<$ when I choose myself, I try more to complete that work. It is funny, but there is no one to blame then>;).

When negotiating with students and creating conditions for making choices, the teacher's role is not made insignificant. Without getting into a greater detail about changes in student and teacher roles, the research demonstrated that the teacher's point of view towards a student, one's advice, and support to students is important and provokes assuming more initiatives and responsibilities (<sometimes it is difficult to choose what would you want, you search for an easier option. The teacher noticed that I behaved in such a way and started negotiating with me, whether I would like to try solving more complex problems $>$ ).

The aspects of manifestation of cooperation among students and between students and teachers demonstrate that sustainable development of students' assumed responsibility for their learning is a reciprocally significant process of co-creation including diversity of components that are characteristic to this process, those supporting invitation to negotiate with a teacher or among peer students, and to make one's proper decisions. This also means assuming responsibility for own learning. 


\subsection{Intervening Conditions for Students Assuming Responsibility for Learning}

On the ground of emphasized categories of collegial negotiation and creation of opportunities to choose, the components-intervening conditions-were pointed out: making students' experiences relevant, clear criteria, attitude towards failure, attitude towards oneself as a major resource of learning, expectations, goals of learning, learning about learning, feedback (Figure 3).

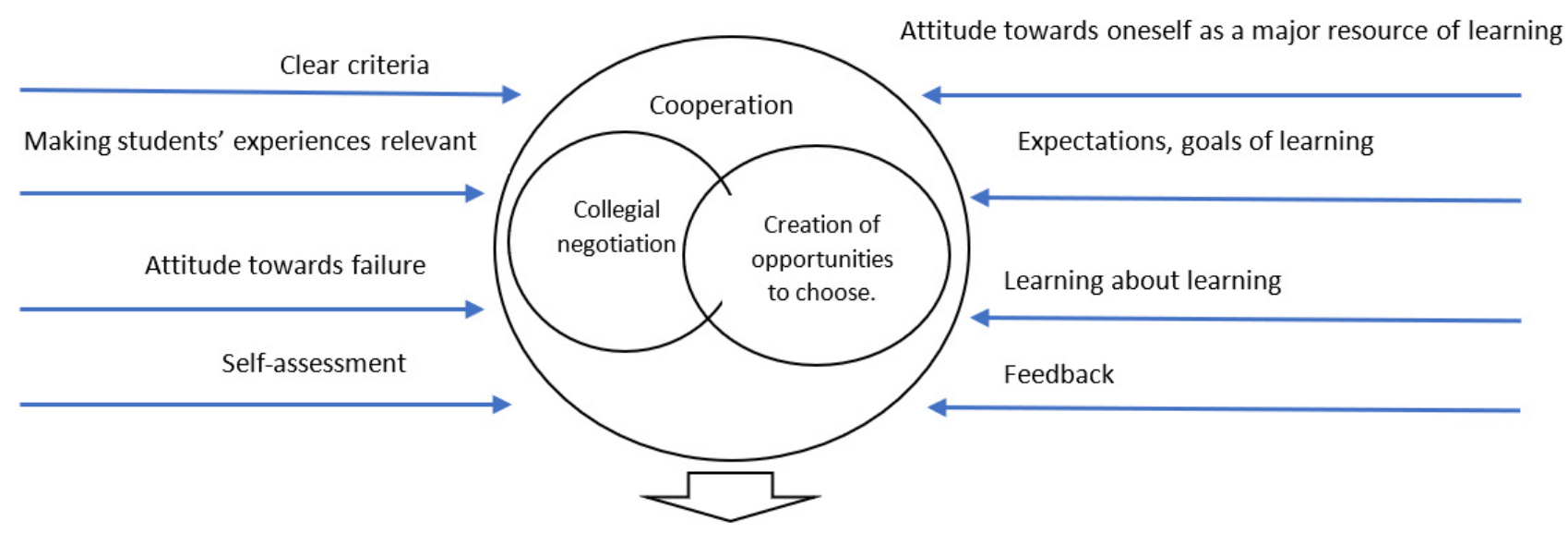

Assuming responsibility for own learning

Figure 3. Provisions, strategies, and intervening conditions for students assuming responsibility for the process of learning.

Further, manifestation of intervening conditions in the process of learning determining putting major strategies to (self-) action seeking assumed students' responsibility for learning will be discussed.

\subsubsection{Intervening Condition "Making Students' Experiences Relevant"}

As observed, students make decisions grounding on already obtained experiences. It may not necessarily be obtained at school to be successfully used when learning and for that obtained experience become part of the system of competencies being developed during learning.

The research demonstrated that students had difficulties in or completely could not decode their obtained experience: (<when I asked children what have already known about that, maybe you already know something, in many cases I received an answer "I know nothing", "I do not know everything", "I have no experience" $>$; $<$ many children think that they and their wish remain at the primary spot only and that everything starts from a zero>).

A problem of connection between obtained experience and goal sought for was found out. It is especially characteristic to experience which was gained outside lessons and which had to be used seeking goals related to learning at school $(<\mathrm{I}$ became aware that if the goal is not related to learning, children say that they did not learn this during lessons, only someone told about it, but they do not treat this as experience to ground on>).

The use of obtained experience by students is very limited if a teacher or other students do not help to make it relevant. This happens when asking additional questions provoking to share obtained experience; later experience is repeatedly considered and critically assessed in the aspect of sought goals ( $<\mathrm{I}$ understood that I need to search for ways hot to show that children's experience to them, that anyway they already know and are able to do something, perhaps they have heard about it, saw or maybe someone told them-this is also experience and it can be useful >; <in order to make children move, I needed to ask additional questions. One child opened up very beautifully when I asked how did his wish appear to set such goal. When he said that his brother was there, I asked to continue him talking about what the brother told him when returned. And then it appeared that he knows much about it and that he can use it $>;<$ After some time children 
start more bravely considering their experience, their strengths, point out as advantages saying that they are brave, self-confident, are obstinate and that this can be useful to one when seeking goals $>$; <you said that you learned to swim during holidays ... >).

When working in group, students make each other's experiences relevant. When discussing, they often name each other's experience with encouragement, emphasize experience as a condition that renders opportunities to find solutions for specific tasks ( $<$ thus, you are able to cut, glue, here it only needs to be done from a different angle $>$; $<$ you always do your homework, and now you will do $>$; $<$ if noise disturbs you, go to a library, then nobody will disturb you >. Often, when presenting answers to initial questions, children remember many significant things (<you attend basketball training activities, perhaps you are able to do good throws of the ball? $<\ldots$ > Yea, I also can dribble the ball with one hand for a long time, I know what is the place that I shoot best ... >).

When making decisions related to learning, even those experiences which are not favorable to learning in their essence can serve for the sake of better learning based on learner's own initiative (<students completed the task where they had to choose their strength and to think how they could use it to perform better at school. One girl said that she hates school very strongly and does not know how to use this. $<\ldots .>$ She thought that she would ask the teacher what they would learn next lesson, then learn at home and when arriving in classroom she would ask questions others. $\langle\ldots\rangle$ She made that decision herself and followed it $\langle\ldots\rangle$. This is a model of swapped classroom $>\ldots$ ).

\subsubsection{Intervening Condition "Attitude towards Oneself as a Major Resource of Learning"}

It was often possible to decode that a teacher, friends, books, the Internet, parents, proper nutrition, sufficient sleep, etc., helped students to cope with difficulties. Application of learning goals, success criteria and ways of acting practically created conditions for students to see themselves and their capabilities (<we were given a task where we needed to fill in with our strengths. After that, we needed to choose three top strengths and write how I will use them to make a better model of a castle for the history lesson. I did not think that my traits can help $>$; <maybe it is easier when you expect that other can help. I will be more self-confident $>$; < what I used the SMART methods, I managed to do my homework faster and could go outside wearing new shoes $>$; $<\mathrm{I}$ do not manage to start doing my homework, I do not make myself do it. But I set a goal for that week-to start after one hour when lessons end. I understood that I am able to do much but was lazy earlier $>$ ).

As a result, students start more often searching for ways what they can do first, and later they ask for help $(<\mathrm{I}$ take a look at the task, the criteria once again and if I really don't understand I turn to friends $>$; < when I know what obstructs my learning, I can do something myself and not only blame others $>$ ).

Observing students' actions and expressed attitudes, teachers applied more approaches focused on cognition of the self as learners in the education process $(<\mathrm{I}$ was searching for ways so that they could discover themselves as much as possible in the process of learning >; <I do not give any piece of advice, I "lead" while questioning, so that they could discover the answer themselves and think what they understood about themselves $>$; $<$ I do not prove their mistakes. I always find a strong feature, e.g., I encourage for courage if a wrong answer was pronounced $>$ ).

\subsubsection{Intervening Condition "Attitude towards Failure"}

When negotiating in the classroom and making decisions, it was found that it depends on participants' (the teacher's and students') attitude towards failure what the final result would be, and if any. Different responses to failure are determined by different attitudes to it and different explanation to the self. Both the teacher's and students' response to failures, without analyzing long-term effect, has a clear momentary effect which can both stimulate search for agreement and joint decision-making and block them, i.e., conditions the assuming of responsibility for own learning. 
Teachers focusing on what a student can learn from one's failure helped them to understand that experience is not fixed and that they can improve that situation by putting efforts: $(<\mathrm{I}$ failed and that the teacher can write a good grade not now, I still need to try harder to make less mistakes $>;<$ I understood that I need to start doing earlier, I did not manage to do in one evening $>;<$ I was praised for efforts, even though the grade is low. Next time I will be braver $>$; $<$ I did not understand how to do, I did not ask myself, the teacher suggested to come after lessons to find out $>$; <even though I have difficulties in mathematics, but the teacher was glad that I am a good athlete, have will and need help, I will learn>).

Both teachers and students do not attribute experienced failures or mistakes to personal characteristics and future prospects: $(<$ we lost the match, sad. Otherwise we are strong, there will be more chances to show off $>;<$ I thought I would manage to complete, but I wasn't on time. But I am not a lazy head, I know that I will do, if needed, I will spend more time $>$; $<$ I will try if I fail with this-but at least I will know that I still need to wait $>$; <otherwise, I learn well, but sometimes I get bad grades, too, I make mistakes, do not learn enough, but try and then do well again $>$; <when I and my peer did wrong tasks, the teacher said that we should be more attentive next time, she did not write a bad grade>; $<$ the teacher told that when she was a school students and did not know everything well, she would make mistakes herself, but, well, she has become a teacher>).

It appears that, despite the mistake made, the value and respect of a student as a personality does not decrease; here, demonstrated efforts are valued. They are allowed to feel that a teacher is a person whom they can trust and whom always to talk to about any mistake they have made: ( $<$ I gave a wrong answer, but the teacher thanked me for I have tried $>$; $<$ when negotiating we follow the rule-to say thank you for an opinion, even it might be on a wrong subject $>;<$ I couldn't wait I told to the peer that he was a gaper. The teacher talked to me kindly, but did not write any note. I apologized myself and everything went well $>$; <when I was asked I didn't know what to answer. The teacher said that it was alright, that sometimes she gets confused, too $>$ ).

\subsubsection{Intervening Condition "Learning about Learning"}

Learning about learning is a form of meta-cognition. Pintrich [68] underlines that meta-cognition encompasses information on self-cognition, tasks and their context, and employed strategies. Knowledge of meta-learning that was revealed during the investigation encompassed knowledge about the self as a learner, and tasks and strategies to complete with them: ( $<$ I understand best when I try to explain to another $>;<$ When I need to read a big book, I eat a small piece of chocolate after each ten pages, then I manage to read faster $>$; $<$ it must be quiet for me, if anyone makes noise, I cannot concentrate>).

This intervening condition was highlighted by attention which was focused on students' understanding about learning and manifestation of meta-learning skills, when it is stimulated and supported in processes of planning, observation and assessment by both teacher and other students or is decoded after performed practice of actions by a learner himself/herself.

Students' knowledge on meta-learning that was revealed during the investigation encompassed knowledge about the self as a learning, and tasks and strategies to complete them: <I understand best when I try to explain to another $>$; <when I learned to break a task into smaller pieces it becomes easier, you can even start not from the beginning $>\ldots<\mathrm{I}$ enjoy starting from an easier piece $>;<$ I am already ready because I can make a presentation without the teacher's and others' help $>$ ).

Students' understanding of learning and skills of meta-learning is stimulated and supported by a teacher asking purposeful questions, presenting cues before the task, during it, or after completion of it $(<$ Who would help to better plan your actions: drawing of a scheme, writing a journal, something else? $>$; <what actions did you take first? And then $>$; $<$ Do you always manage to independently complete a task till the end? What it depends on $>;<$ What is the importance of ideas about contribution to the common result 
said by other members of the group? $>$; $<$ How do you decide that you have done the task correctly?>; <Are you satisfied with the result of your work? Who has most influence on you being satisfied?>).

Manifestation of students' understanding of learning and skills of meta-learning when it is provoked by cooperating peer students was observed: ( $<$ so how do you know $>$; $<$ And how will you explain that ... >; <these are only your thoughts or did you read them somewhere? >; <so you take that activity which you are best at $>$; $<$ we could do better if we all would contribute $>$; $<$ the things that obstruct us from moving forward are ... $>$; $<$ how do you assess your point of view towards our joint work? $>$; $<$ What do we know so that we could help ... >; <when you start directing all others, then ... $>$ ).

Next, manifestation of students' understanding about learning and skills of metalearning is enhanced by their own thoughts arising after practicing learning: $(<\mathrm{It}$ is better for me to remember when I make a map of concepts, draw which one links to another $>$; $<$ when I approach that place, I stop and don't know what to do. I asked to help me because sometimes I fail myself $>$; <it must be quiet for me, if someone makes noise, I cannot concentrate $>$; $<$ I get a better grade when I attentively listen to the teacher's explanation $>$; $<$ I know that I need think with my head and not be absent minded $>$; $<$ I was thinking about that idea for a long time. I enjoyed thinking about it $>;<$ I must go to bed earlier so that I could concentrate during the lesson $>;<$ I was disturbed by various foreign thoughts and I could not focus $>$ ).

It is important to note that perception of learning as being different allows recognizing differentness of others' learning, to see the value of differentness for own learning or the value of differentness of own learning to others ( $<$ I would become nervous when I am paired with a nerd, but now I think that it is good when I can ask $>;<$ I understand that I not necessarily must do as much as other do, but still I wish to not lag behind $>$; $<$ I like to jointly search for ways how to do this, then everyone suggests something, it becomes easier>; $<$ not all equally contribute, some can do more, others less, they you get a grade for that, not all get the same grade, then you can try>). It is likely that understanding of diversity of learning can become a condition for prevention of bullying based on learning differences.

\subsubsection{Intervening Condition "Expectations, Goals of Learning"}

In the course of the investigation, it was found that the determined preconditions for identifying this intervening condition manifested in the following aspects: First, through benefit to learners and through techniques that were agreed to be applied by the teacher and students. It can be stated that this cannot be a formal procedure only ( $<$ I clearly understood that you cannot announce the goal at the beginning of the lesson. Presented objectives would have no purpose if I told the goal of the lesson $>$; < sometimes it is better not to say topics of lessons to students $>$; <not always one can find words to exactly name the goal of a lesson $>$; $<$ when a topic is interesting, I want to search for the answer myself. And when the teacher says what we will learn today, the interest disappears because it already reveals much. Why to go deeper then?>) because an opportunity to engage students in the process of learning might be lost and students are pulled away from it.

Assuming of responsibility for own learning is inspired when learning goals are defined jointly with students ( $<$ when we were searching in our group for ways to show our created ideas about the body, we became aware what we needed to go deeper into. Then we set a goal together with a teacher >; <where I fail when competing a task, I usually get stuck. Then I need help—to set a goal together with a teacher $>$ ). This illustrates that students are capable of applying these learning goals in their activity.

Another important aspect that was highlighted in relation to learning goals was the formulation of learning goals being unrelated to the context, which created conditions for students to be active in the process of learning (<when I separate the learning goal from the learning context, it becomes much easier for me to differentiate the process of teaching $>$; $<$ I do not link the goal to the context. I include it into the criteria, differentiate according to students' learning needs. Therefore, when there are many students in the classroom, 
they can seek the same learning goal>; <earlier I would formulate a goal or objectives so that all had clear and equal context. Now I understand that I focused on some kind of a standard. Some students would complete fast, others failed. Now I understand why both more gifted students and other ones would not engage $>$ ).

Grounding on the results, clarity of the wording of learning goals is highly relevant and provides conditions for assuming responsibility for own learning. Students are more in favor of the formulation of learning goals which are presented in a "friendly" language to them (<sometimes I do not understand how teachers write. Many various words. Then I do not pay attention $>$; $<$ if teachers did not tell the goal maybe it was clearer. Sometimes there are words which confuse me $>$; $<$ when we agreed with the teacher how we could formulate better, it was not easy. But I know that it must be clear to me $>$ ). Therefore, as a result of common agreements, teachers changed wording into those formulated in the language acceptable to students (<you can apply the methods for time planning $>$; $<$ I can use my strengths when doing homework $>$ ).

\subsubsection{Intervening Condition "Clear Criteria"}

One of the most obvious needs for clear criteria was based on a situation that not all students' understanding of what they should learn during lessons was identical to that of their teachers $(<\mathrm{I}$ don't know everything what is expected of me. Often I try to guess $>;<\mathrm{I}$ put so much effort but it appeared that it needed to be done in a different way $\rangle$; <every time the teacher, perhaps, changes her mind because my works do not look good to her $>$ ). This was especially emphasized when dealing with assessment and self-assessment $(<$ the teacher not always justly assesses me $>$; $<$ she did not tell that we will have to account for that $>$; $<$ I thought that this information was unimportant, but it occured that it was important for the teacher $>$ ). Teachers and students emphasize not only the availability of criteria but also clarity of them. Formulations of such either stimulate engagement in work or create confusion even more $(<\mathrm{I}$ can do the work independently now. I decide myself where I will start. But all criteria must be clear to me. If not, then I consult the teacher of a friend on what this could mean $>$; <we agreed with students that we will formulate them in a form of a suggestion: choose the key words, characterize similarities, etc. $>$; $<$ my students greatly enjoyed the formulation through using the construct "I can": I can characterize my strengths, I can tell what I give most time for $>$ ).

An advantage of formulation of criteria jointly with students is that it helped to create a specific mechanism allowing students discuss learning goals and criteria, as well as to assume personal responsibility for them ( $<$ if I had no goal, why are these criteria needed for them. Then it is very hard to do everything alone $>$; $<$ when we were learning to set a goal, I was very glad because I will be able to learn independently. But this did not happen. I understood that criteria are needed, too, so that I could see if I have achieved that goal $>$ ).

Such activity is enhanced when students are able to apply these criteria in their activity. The research results allowed emphasizing this intervening condition through how differentiation of success criteria was revealed in the process according to how students are capable of applying gained knowledge in a different environment $(<$ when we were repeating the topic on power during our physics lesson, I suggested that we could present an illustration and literature works as examples of the power $>;<\mathrm{I}$ agreed with a teacher that I would like to write a recommendation, a different one from those that other were writing in the classroom (about famous places for sightseeing in the town), the one that would be addressed to basketball fans $>$ ).

The process of this investigation pointed out the worth of thinking of whether students must employ only these criteria that are indicated. It was observed that if students trusted their capacities and knew how to work, these criteria could be eliminated ( $<$ when writing a creative task, students refused criteria because they wanted to start narrating the story not from the beginning but from the end $>$; <the written criteria included that first of all we solve the task in a draft. But I solve everything in my exercise book from the beginning because it is very easy>). 
After the need for formulation of criteria was found, teachers changed their actions. This influenced the change of their attitudes related to their role. They made themselves more active as <coachers for understanding school students and not only implementers of content or activity $>$ and now pay most attention to $<\ldots$ assurance of learning, not only teaching $>$.

\subsubsection{Intervening Condition "Self-Assessment"}

When creating conditions for students to assume responsibility for their own learning, the process of self-assessment as an intervening condition transformed both the process and the result. Reconstruction of the design of the entire education process is emphasized as an example of the transformation of a process: in transition from planning and organization of the traditional education process to backward design, understanding by design. Teachers observed that their efforts were directed to organization of activities intended for students ( $<$ if there is any topic, I would think what interesting tasks I would give $>$ ). The change that took place during the investigation process created conditions for teachers to construct the approach of the backward design, understanding by design, themselves (<if I cannot tell it myself, what will students learn from the interesting tasks I give, how can they self-assess what they have learned > ; <even how clearly I would articulate the expectations of learning, students refused any responsibility>; <earlier twice as many textbooks, scope of tasks were needed $>$ ). As a result, the process of self-assessment has become meaningful to both students and teachers because it meets the set goals and success criteria (<it is easier to self-assess now. I know according to what $>$; <now I can tell if I have achieved my goals or not. More, I can tell where I am, if I haven't achieved the goal yet>; <students self-assess themselves, no explanation of pushing is needed $>$ ).

\subsubsection{Intervening Condition "Feedback"}

Preconditions to identifying this intervening condition manifested most clearly in the following aspects: manifestation of a character of provision/reception of feedback (facilitating or controlling) and manifestation of a condition for students to assume responsibility for learning (activates or subdues); how collegial feedback provokes both teachers and learners to change strategies of their activity to create more favorable conditions for students to assume responsibility for learning.

The research highlighted that cooperation taking place in the culture of dialogue provokes partnership between student and teacher, and among peer students where information on success and difficulties in learning is shared, where a learner is facilitated to consider own process and results of learning and take further actions to change the situation. In the culture of dialogue, it acts more as a personal suggestion or request to change: $(<\ldots$ you presented a proper example of what you state, you illustrate with examples ... $>;<\ldots$ there are strengths-you presented illustrations, arguments, but there spelling mistakes. What do you think was that determined making them? What could you do to not repeat them?>; < . . what, in your opinion, could help you in this issue? ; $<$ I understood that not now yet we can expect this work done. What difficulties occurred? How can I help you?>; <somehow we need to select the best ideas of the project. What suggestions have we got how to do it?>; <thank you for trying. It helped out group very much that you did not give up and showed an example to others ... >).

Provided/received feedback can also be rejected or not necessarily accepted when it becomes a forced impulse to change the self. The research revealed that a character of feedback is either controlling or provided as instruction; it provokes a sense of guilt, evokes resistance of students, and this does not encourage students to assume decisions improving their learning: (<so, it is so simple here, don't you know? >; <I became nervous, I did it continuously bad several times ... $>$; $<$ when she asked why it happened, I felt uncomfortable because I remain the most guilty in that situation . . . ; < replied incorrectly, the teacher said that I need to think what I say. I don't know, I had difficulties in thinking at all ... > ; <why did you tell about that only now?>; <the teacher said that I tried 
insufficiently >; <peers said that I need to think myself, I made an idea myself anyway . . > ; $<$ they did not include my part of the work, even though I did it well. They said that I did not follow the rules. These foolish rules, let they do the work themselves $>$ ).

Collegial feedback that manifested in the research helps teachers to receive valuable information from students about organization of the process and provokes to change strategies of activity to create more favorable conditions for assumed students' responsibility for learning: $(<$ I understood from students' questions that I must find the ways how to demonstrate them in an understandable way that I will not do anything if they do not put their efforts >; <self-assessment of students allowed me to understand that I still need to make the success criteria more specific, a result must be clearly seen, loosely defined verbs should be avoided. I must work harder on this myself $\rangle ;\langle\ldots$ teacher, how to find out when it is enough, when it is, well, good?>; <when they started listing what they were not able to do, what they did not know, even though they assessed themselves with high grades, I started suspecting that they have low self-confidence. I need to think about strategies which would enhance their self-confidence $<\ldots>$ ).

The practice of learning and changes taking place in the context of it provoke students to seek feedback and take actions: $<$ I want to know how I succeeded . . > ; $<\ldots$ what can I change, where to improve myself $>;<\ldots$ I want to get a higher grade. What additional work could I do?>; < please tell what strengths do you see?>; <and are these sources that I indicated suitable, sufficient?>; <and why not now? Do I have to present more evidences?>. Such feedback acts not as a forced impulse but rather as a personal suggestion and an offer of changes.

\section{Discussion and Conclusions}

For the sustainable development of students' assumed responsibility for their learning, not only the analyzed problem is relevant but also the way the result of the problem under analysis is being sought for, i.e., what methodology is applied. Action research is a systematic research approach whose democratic, cooperative, and participatory processes enable people find solutions for relevant, real-life problems [60]. This means that assurance of sustainability was conditioned through partnership and cooperation; justice and equity; and sustainable, enduring relationships.

UNESCO publications consider that there is a striving issue to maintain the democratic philosophy of knowledge production using methods of knowledge production that encourage creation of shared knowledge. In this case, alternative local knowledge also can be used when solving a large present-day challenge. Therefore, knowledge democracy and action research give a perfect opportunity to view a new prospect in light of the actual major problems [69].

Participatory action research provided conditions for all interested individuals to engage in the change of the education process (by applying "playful" methods meeting participants' needs), to see how participants of the education process reconstruct practice themselves, and how they react to changes. We hope that this action research will encourage pedagogues and researchers to continue investigation on how to stimulate equal "voice" of all participants of the education process (teachers, school students) in a classroom while systematically performing actions and considerations that inspire to think when creating own pedagogy and develop the field of community research-based pedagogy.

Assurance of sustainable development in education processes obliges creating such practices of teaching and learning which would create conditions for individuals to act in difficult situations in a sustainable manner [70]. In the research, the sustainability approach is illustrated through the change of learners' responsibility for their learning (from responsibility to others to responsibility to self). This illustrates that created conditions ensure manifestation of perceived responsibility which has a high social value, including external to intrinsic responsibility (when students became initiators of commitment); from collective to individualized responsibility (do not want to avoid responsibility assumed by their free will); from responsibility as a control to responsibility as self-control (self- 
assessing); and from responsibility for the past to responsibility for the future (when they think of responsibility not when something wrong happened but well before assuming it, assessing a situation, own capacities to act in it and so on).

Grounding on the research results, the conditions (cooperation), strategies (collegial negotiation, creation of opportunities to choose), intervening conditions (making students' experiences relevant; clear criteria; attitude towards failure; attitude towards the self as a major resource of learning; expectations, goals of learning; learning about learning; feedback) for students to assume responsibility for their learning were revealed. The approach of participatory action research created an opportunity not only to understand actions but also to ground them. Such processual approach ensures self-development of independence in students $[32,51,52]$. The research pointed out not only provisions, strategies, and intervening conditions, but also their reciprocal integrity, and complexity.

Slavin, Hurley, Chamberlain [71] in their research pointed out that "research on cooperative learning is one of the greatest success stories in the history of educational research" (p. 177). The research conducted by the authors points out that when focusing only on cooperation and not regarding the strategies that operate in it (in the case of this research, collegial negotiation, creation of conditions to choose), management of intervening conditions it is hardly possible to make an effect on students assuming responsibility for learning. Therefore, the strategies and intervening conditions dominating in the context of cooperation emphasized in the research created conditions for students to assume responsibility for their own learning.

When assessing manifestation of intervening conditions in the aspects of importance and consistency, we emphasize that there is no other more or less important, primary or secondary one - they all depend on each other, manifest in a complex manner, and the manifestation of one condition leads to manifestation of the other.

As observed, choices and decisions are being made while following already obtained experiences [17]. As a result, the conducted research emphasized the intervening condition-"making students" experiences relevant". When talking about decisions which are important to learning, experience not necessarily must be gained at school to successfully use when learning and for the obtained experience to become part of the system of competencies being developed in the course of learning. Grounding on the research data, students have difficulties in making it relevant and linking to the goal of learning to be achieved without support of others (teacher or peers). During cooperation, searching for agreements and making decisions, experiences are being highlighted and usually act as a condition for the decision-making. Moreover, it is being supplemented with available and new experiences of others that occur while being actively engaged. It is important that even having an identified experience which is unfavorable for learning, prompted by learner's initiative, it might serve for the sake of better learning if an approach to it as useless and deniable is not being stimulated externally.

Grounding on the research results, it depends on the attitude towards failure how actively students engage in solving problems related to learning. When provoking students to discuss on what conditioned success, what they learned from it, how their efforts can help to avoid failure or change a situation, allow them to make decisions regarding their own learning more bravely. This also means feeling more responsible because they understand that, in many cases, success depends on fostering efforts. The importance of response and what proceeded before failure and after it, were pointed out in the research. Students' proper reaction to it depends also on the teacher's actions. Not without purpose, Haimovitz, Dweck [72] point out that the response of adults to students' failures makes an impact on their thinking and potential for success, which influences motivation and learning. Researchers provide evidence about a teacher's comments being focused on recognition of efforts, and this stimulates positive self-evaluation and higher persistence, and brings students together for further learning. Students need to believe that their efforts will help them to learn and that this will contribute to implementation of their goals. 
When creating conditions for students to assume responsibility for their learning, provided/received "feedback" was emphasized as one more intervening condition determining further actions of a learner and a teacher not by accident [73]. Feedback can be an instrument of co-creation of assuming responsibility for own learning related to other emphasized intervening conditions and determining the manifestation of them. Depending on whether it is facilitating or controlling, other intervening conditions manifest respectfully (e.g., learning about learning, attitude towards failure, towards oneself as a major resource of learning, (un)making experience relevant, etc.) and it depends on whether a wish to assume responsibility for own learning is being activated. Feedback acts not as a forced impulse but as a personal suggestion and self-suggestion to change oneself; research on this in relation to other intervening conditions may be a future prospect to encourage students to assume responsibility for own learning.

We linked in-depth feedback to oneself on own learning that was pointed out while reflecting practice of learning and changes taking place in the context of it, to meta-learning and called it learning about learning. During the research, it was emphasized that those school students who are unable to consider their learning only through cooperation engage in processes that encompass information on self-cognition, task, and self-regulation. Such self-engagement of students in processes of meta-learning expands the perception of these processes and is a condition for making the relation of the learners with learning processes and results, which refers to responsibility for own learning, relevant.

Moreover, deeper perception of learning processes allows understanding that learning outcomes can be achieved in very different ways and levels, which basically modifies the attitude towards peers who learn in different ways. It is important to seek prevention of discrimination occurring from earning differences among learners, which can negatively impact further personal development, influencing not only attainments but also further success in one's life [10,12].

Grounding on the research results, we can declare that clarity of formulation of the intervening condition "expectations, goals of learning" is highly relevant to students and provides conditions for them to assume responsibility for their learning. Wiliam [16] pointed out that often is it worth defining learning goals jointly with students and call this process "co-construction". During the research, it was found that students more strongly favor these formulations of learning goals which are constructed in a language that is "friendly" to them. This emphasizes the importance of language that is acceptable to school students in learning and remind not to forget to learn the "official" language of a subject in parallel because this is also a part of the process.

Results of a research conducted by Boud, Lawson and Thompson [74] reasoned a significant effect on students' learning from consistent assessment criteria intended for improvement of individual decisions. Manifestation of the intervening condition "clear criteria" illustrated that it depends on availability of criteria and clarity of formulation in the process of learning whether students will engage in the process of learning or this will create even more confusion. Clear criteria can help reduce students' anxiety and encourage the use of self-regulatory learning strategies, which results in students assuming more responsibility for their learning. On the other hand, clear criteria can limit independence and creativity of students [75]. The process of this research emphasized that it is worth thinking of whether students should always refer only to the criteria that are indicated. It was observed that if students trust their capacities and know how to work, these criteria may be rejected.

The research also emphasized that students more willingly assumed responsibility for their learning when they took part in negotiations about criteria. Learning criteria were differentiated according to how students are able to apply knowledge in a different environment. In the course of such process, the change of teachers' attitudes related to their roles happened. They became more active as learning coachers and not only as implementers of content or activity. 
The intervening condition "self-assessment" that was pointed out in the research created conditions for the transformation of both process and resulted in the aspect of students assuming responsibility for their learning. In the process of teaching and learning, the lesson design was transformed, i.e., there was a transition from planning and organization of traditional educational process to application of the backward design, understanding by design, logic. Wiggins, McTighe [76] investigated the understanding by design as an approach of planning and perception of better teaching and learning processes where attention is focused not on knowledge but rather on development of the true understanding. On the basis of such process, a learner consciously learns while independently engaging in the learning processes. According to Taras [77], empirical research studies prove that self-assessment is an important factor involving learners into learning. When self-assessing themselves, students have a possibility to develop skills of analytical thinking, engaging in the decision-making process [78], wherein a student analyzing his/her performance and results becomes a meaning-seeking researcher.

While reciprocally interacting, the strategies and intervening conditions that dominate in the context of cooperation act as components of sustainable development of students' assumed responsibility for learning. This makes up a specific system that provides conditions for not only self-development of independence but also for elimination of occurrence of discriminative behavior appearing because of learning differences or inequality.

\section{Limitations of the Study and Future Perspective}

Due to their character (applying action research), the conclusions of the research are not to be used for drawing broad, generalizing conclusions. The research conclusions are limited by the context because the purpose of the action research is to generate a problem which is relevant for a particular community only, to make obtained knowledge applicable in practice. Nevertheless, research conclusions may provide insights about specific situations: provisions, strategies, intervening conditions that create conditions for students to assume responsibility for their learning and are oriented towards solutions of sustainable development. The circumstances, strategies, and intervening conditions that were pointed out in the research require more comprehensive investigation (analyzing learners' experiences according to different attainments, role of parents, school culture, etc.) in the context of students assuming responsibility for learning. Current conditions of the new educational reality under the COVID-19 pandemic have impacted in some way the area of students assuming responsibility for their learning, which prompts to assess and analyze this anew, seeking a more effective process of education and conditions that ensure this process. These could be the directions for future research, theoretical development, and practice.

Author Contributions: Conceptualization, A.K. and R.G.; methodology, A.K., R.G. and R.B.; validation, R.B., J.C. and D.C.; formal analysis, A.K. and R.G.; investigation, R.B., J.C. and D.C.; resources, A.K. and R.G.; data curation, A.K., R.G. and R.B.; writing-original draft preparation, A.K. and R.G.; writing-review and editing, R.B., J.C. and D.C.; visualization, A.K. and R.G.; supervision, R.B., J.C. and D.C.; project administration, J.C. and D.C. All authors have read and agreed to the published version of the manuscript.

Funding: This research was funded by the Institute of Sciences Education of the University of Girona, grant numbers XIDAR/03-2021 and XIDAC/03-2021.

Institutional Review Board Statement: Not applicable.

Informed Consent Statement: Informed consent was obtained from all subjects involved in the study.

Data Availability Statement: The data presented in this study are available on request from the corresponding author.

Conflicts of Interest: The authors declare no conflict of interest. 


\section{References}

1. Transforming Our World: The 2030 Agenda for Sustainable Development, A/RES/70/1. Available online: https://www.un. org/en/development/desa/population/migration/generalassembly/docs/globalcompact/A_RES_70_1_E.pdf (accessed on 12 June 2021).

2. Sustainable Development Goals/4 Quality Educations. Available online: https://www.un.org/sustainabledevelopment/ education/ (accessed on 8 May 2021).

3. Eidea, E.R.; Showalter, M.H. Estimating the Relation Between Health and Education: What do We Know and What do We Need to Know? Econ. Educ. Rev. 2011, 30, 778-791. [CrossRef]

4. Edgerton, J.D.; Roberts, L.W.; von Below, S. Education and Quality of Life. In Handbook of Social Indicators and Quality of Life Research, 2nd ed.; Land, K., Michalos, A., Sirgy, M., Eds.; Springer: Dordrecht, The Netherlands, 2012; pp. 265-296. [CrossRef]

5. Teaching and Learning: Achieving Quality for All: EFA Global Monitoring Report, 2013-2014, ED.2013/WS/29 REV Summary. Available online: https:/ / unesdoc.unesco.org/ark:/48223/pf0000225654 (accessed on 14 May 2021).

6. Fishman, E.J. With Great Control Comes Great Responsibility: The Relationship Between Perceived Academic Control, Student Responsibility, And Self-Regulation. Br. J. Educ. Psychol. 2014, 84, 685-702. [CrossRef] [PubMed]

7. Dudley-Marling, C. Social Construction of Learning. In Encyclopedia of the Sciences of Learning; Seel, N.M., Ed.; Springer: Boston, MA, USA, 2012; pp. 182-211. [CrossRef]

8. Reusser, K.; Pauli, C. Co-constructivism in Educational Theory and Practice. In International Encyclopaedia of the Social E Behavioral Sciences, 2nd ed.; Wright, J.D., Ed.; Elsevier: Amsterdam, The Netherlands, 2015; pp. 913-917. [CrossRef]

9. Mohammed, S.H.; Kinyo, L. The Role of Constructivism in the Enhancement of Social Studies Education. J. Crit. Rev. 2020, 7, 249-256.

10. Hong, J.S.; Espelageb, D.L. A Review of Research on Bullying and Peer Victimization in School: An Ecological System Analysis. Aggress. Violent Behav. 2012, 17, 311-322. [CrossRef]

11. UNESCO. Global Education Monitoring Report 2020: Inclusion and Education: All Means All; UNESCO: Paris, France, 2020. Available online: https:/ / unesdoc.unesco.org/ark:/48223/pf0000373718 (accessed on 8 May 2021).

12. Tannock, S. The Problem of Education-Based Discrimination. Br. J. Sociol. Educ. 2008, 29, 439-449. [CrossRef]

13. OECD. Educating Teachers for Diversity: Meeting the Challenge, Educational Research and Innovation; OECD Publishing: Paris, France, 2010. Available online: https:/ / www.oecd-ilibrary.org/education/educating-teachers-for-diversity_9789264079731-en (accessed on 8 May 2021).

14. Hattie, J. Visible Learning, 1st ed.; Routledge: London, UK; New York, NY, USA, 2008.

15. Fletcher, A.K. Exceeding Expectations: Scaffolding Agentic Engagement through Assessment as Learning. Educ. Res. 2016, 58, 400-419. [CrossRef]

16. Wiliam, D. Embedded Formative Assessment, 2nd ed.; Solution Tree: Bloomington, IN, USA, 2017.

17. Gray, A. Constructivist Teaching and Learning; University of Saskatchewan: Saskatoon, SK, Canada, 1997. Available online: https:/ / saskschoolboards.ca/wp-content/uploads/97-07.htm\#Table\%20of\%20Contents (accessed on 12 January 2021).

18. Akpan, V.I.; Igwe, U.A.; Mpamah, I.B.I.; Okoro, C.O. Social Constructivism: Implications on Teaching and Learning. Br. J. Educ. 2020, 8, 49-56.

19. Sasson, I.; Malkinson, N.; Oria, T. A Constructivist Redesigning of the Learning Space: The Development of a Sense of Class Cohesion. Learn. Environ. Res. 2021, 1-15. [CrossRef]

20. Ahmad, S.; Sultana, N.; Jamil, S. Behaviorism vs Constructivism: A Paradigm Shift from Traditional to Alternative Assessment Techniques. J. Appl. Linguist. Lang. Res. 2020, 7, 19-33.

21. Ernest, P. Social Constructivism as a Philosophy of Mathematics: Radical Constructivism Rehabilitated 1999. Available online: http:/ / socialsciences.exeter.ac.uk/education/research/centres/stem/publications/pmej/soccon.htm (accessed on 8 May 2021).

22. Cole, M. Cultural Psychology: A Once and Future Discipline, 6th ed.; printing; Belknap Press: Cambridge, UK, 2003.

23. Domin, D.S. A Review of Laboratory Instruction Styles. J. Chem. Educ. 1999, 76, 543. [CrossRef]

24. Castillo, K.S.; Paper, P. Discovery Learning vs. Traditional Instruction. Position paper. 2008, pp. 1-9. Available online: http:/ / www.csun.edu/ \{\}ksc63842/Posistion_paper.pdf (accessed on 3 April 2021).

25. Goos, M. Learning Mathematics in a Classroom Community of Inquiry. J. Res. Math. Educ. 2004, 35, 258-291. [CrossRef]

26. Wells, G. Semiotic Mediation, Dialogue and the Construction of Knowledge. Hum. Dev. 2007, 50, 244-274. [CrossRef]

27. Juvonen, J. Sense of Belonging, Social Bonds, and School Functioning. In Handbook of Educational Psychology, 2nd ed.; Alexander, P.A., Winne, P.H., Eds.; Lawrence Erlbaum Associates Publishers: Mahwah, NJ, USA, 2006; pp. 655-674.

28. Gillies, R.M. Promoting Academically Productive Student Dialogue during Collaborative Learning. Int. J. Educ. Res. 2019, 97, 200-209. [CrossRef]

29. Belenky, M.F.; Clinchy, B.M.; Goldberger, N.R.; Tarule, J.M. Women's Ways of Knowing: The Development of Self, Voice, And Mind; Basic Books: New York, NY, USA, 1986.

30. Boomer, G. Negotiating the Curriculum. In Negotiating the Curriculum: Educating for the 21st Century, 2nd ed.; Boomer, G., Lester, N., Onore, C., Cook, J., Eds.; The Falmer Press: London, UK, 1992; pp. 4-14.

31. Cook, J. Negotiating the Curriculum: Programming for learning. In Negotiating the Curriculum: Educating for the 21st Century, 2nd ed.; Boomer, G., Lester, N., Onore, C., Cook, J., Eds.; The Falmer Press: London, UK, 1992; pp. 15-31. 
32. Shah, R.K. Effective Social Constructivist Approach to Learning for Social Studies Classroom. J. Pedagog. Res. 2019, 3, 38-51. [CrossRef]

33. Brooks, M.; Brooks, J. The Courage to Be Constructivist. Educ. Leadersh. 1999, 57, 18-24.

34. Topping, K.J.; Buchs, C.; Duran, D.; Van Keer, H. Effective Peer Learning: From Principles to Practical Implementation; Routledge: London, UK; New York, NY, USA, 2017.

35. Alexander, R.J. Culture, Dialogue and Learning: Notes on an Emerging Pedagogy. In Exploring Talk in School: Inspired by the Work; Douglas Barnes; Mercer, N., Hodgkinson, S., Eds.; SAGE Publications Ltd.: London, UK, 2008; pp. 91-114.

36. Salih, U.; Melek, K. The Outcomes of Constructivist Learning Environments from the Perspectives of Secondary School Students. Int. Educ. Stud. 2020, 13, 16-28.

37. Gash, H.; Murphy, F. The Ecology of Teaching and Learning. Constr. Found. 2020, 15, 118-121.

38. Arroyave, F.; Dasí, A.; Redondo, A. Student Commitment to Social Responsibility: Systematic Literature Review, Conceptual Model, and Instrument. Intang. Cap. 2021, 17, 52-72. [CrossRef]

39. Chin, C.; Donnell, A.; Jinks, T. The Structure of Discourse in Collaborative Learning. J. Exp. Educ. 2000, 69, 77-89. [CrossRef]

40. Veenman, S.; Denessen, E.; van den Akker, A.; van der Rijt, J. Effects of a Cooperative Learning Program on the Elaborations of Students During Help Seeking and Help Giving. Am. Educ. Res. J. 2005, 42, 115-151. [CrossRef]

41. King, A. Structuring Peer Interaction to Promote Higher-Order Thinking and Complex Learning in Cooperating Groups. In The Teacher's Role in Implementing Cooperative Learning in the Classroom; Gillies, R.M., Ashman, A.F., Terwel, J., Eds.; ComputerSupported Collaborative Learning, 8; Springer: Boston, MA, USA, 2008. [CrossRef]

42. Gillies, R.M.; Khan, A. The Effects of Teacher Discourse on Students' Discourse, Problem-Solving and Reasoning during Cooperative Learning. Int. J. Educ. Res. 2008, 47, 323-340. [CrossRef]

43. Howe, C.; Tolmie, A.; Thurston, A.; Topping, K.; Christie, D.; Livingston, K.; Jessimanc, E.; Donaldsonc, C. Group Work in Elementary Science: Towards Organisational Principles for Supporting Pupil Learning. Learn. Instr. 2007, 17, 549-563. [CrossRef]

44. Bardach, L.; Yanagida, T.; Morin, A.J.S.; Lüftenegger, M. Is Everyone in Class in Agreement And Why (Not)? Using Student and Teacher Reports to Predict Within-Class Consensus on Goal Structures. Learn. Instr. 2021, 71, 101400. [CrossRef]

45. Sheridan, D. Teaching Secondary English: Readings and Applications; Longman: New York, NY, USA, 1993.

46. Benson, P. Teaching and Researching Autonomy in Language Learning; Longman: London, UK, 2001.

47. Calkins, L. The Art of Teaching Writing; Heinemann: Portsmith, NH, USA, 1986.

48. Kumar, A.; Teotia, A.K. Constructivism: A Dynamic Approach of Teaching. Int. J. Manag. Appl. Sci. 2017, 5, 135-139.

49. Applebee, A.N. Literature in the Secondary School: Studies of Curriculum and Instruction in the United States; National Council of Teachers of English: Urbana, OH, USA, 1993.

50. Langer, J.; Applebee, A.N. How Writing Shapes Thinking: A Study of Teaching and Learning; National Council of Teachers of English: Champaign, IL, USA, 1987.

51. Whalen, B. Education Abroad and the Undergraduate Experience: Critical Perspectives and Approaches to Integration with Student Learning and Development; Stylus Publishing, LLC: Sterling, VA, USA, 2019.

52. Darling-Hammond, L.; Flook, L.; Cook-Harvey, C.; Barron, B.; Osher, D. Implications for Educational Practice of the Science of Learning and Development. Appl. Dev. Sci. 2019, 24, 97-140. [CrossRef]

53. Brydon-Miller, M.; Greenwood, D.; Maguire, P. Why Action Research? Action Res. 2003, 1, 9-28. [CrossRef]

54. Brydon-Miller, M.; Kral, M.; Aragón, A.O. Participatory Action Research: International Perspectives and Practices. Int. Rev. Qual. Res. 2020, 13, 103-111. [CrossRef]

55. Kemmis, S.; McTaggart, R. Participatory Action Research. In Handbook of Qualitative Research; Denzin, N., Lincoln, Y., Eds.; Sage: Thousand Oaks, CA, USA, 2000; pp. 567-606.

56. Groundwater-Smith, S.; Dockett, S.; Bottrell, D. Participatory Research with Children and Young People; Sage: Los Angeles, CA, USA, 2015.

57. Flanagan, J.C. The Critical Incident Technique. Psychol. Bull. 1954, 51, 327-358. [CrossRef]

58. Cohen, L.; Manion, L.; Morrison, K. Research Methods in Education; Routledge: New York, NY, USA, 2018.

59. Flick, U. An Introduction to Qualitative Research, 4th ed.; Sage: London, UK, 2009.

60. Bradbury, H.; Reason, P. Conclusion: Broadening the Bandwidth of Validity: Issues and Choice-Points for Improving the Quality of Action Research. In Handbook of Action Research: Participatory Inquiry and Practice; Reason, P., Bradbury, H., Eds.; Sage Publications: London, UK, 2001; pp. 447-455.

61. Zuber-Skerritt, O.; Fletcher, M. The Quality of an Action Research Thesis in the Social Sciences. Qual. Assur. Educ. 2007, 15, 413-436. [CrossRef]

62. Carr, W.; Kemmis, S. Becoming Critical: Education, Knowledge and Action Research; Deakin University Press: Geelong, Australia, 1986.

63. Zuber-Skerritt, O. Action Learning and Action Research: Paradigm, Praxis and Programs. In Effective Change Management Using Action Research and Action Learning: Concepts, Frameworks, Processes and Applications; Sankaran, S., Dick, B., Passfield, R., Swepson, P., Eds.; Southern Cross University Press: Lismore, Australia, 2001; pp. 1-20.

64. Kalsem, K. Anonymity, Privacy, and Confidentiality. In Ethics in Participatory Research for Health and Social Well-Being; Routledge: New York, NY, USA, 2019.

65. Brydon-Miller, M.; Rector-Aranda, A.; Stevens, D. Widening the Circle: Ethical Reflection in Action Research and the Practice of Structured Ethical Reflection. In The Handbook of Action Research, 3rd ed.; SAGE: Thousand Oaks, CA, USA, 2015. 
66. Boser, S. Ethic in Power in Community-Campus Partnerships for Research. Action Res. 2006, 4, 9-22. [CrossRef]

67. Coghlan, D. Doing Action Research in Your Own Organization; SAGE: Thousand Oaks, CA, USA, 2019.

68. Pintrich, P.T. The Role of Metacognitive Knowledge in Learning, Teaching, and Assessing. Theory Pract. 2002, 41, 219-225. [CrossRef]

69. Tandon, R.; Hall, B. UNESCO Chair on Community Based Research and Social Responsibility in Higher Education; PRIA and GACER, University of Victoria, School of Public Adminstration; PRIA: New Delhi, India; University of Victoria: Victoria, BC, Canada, 2012.

70. Daujotienè, L.; Kazlauskienè, A.; Bubnys, R. Teacher Involvement in Organisational Change: From Engaging Risk to Cooperative Learning. Sustainability 2020, 12, 9447. [CrossRef]

71. Slavin, R.E.; Hurley, E.A.; Chamberlain, A.M. Cooperative Learning and Achievement. In Handbook of Psychology; Reynolds, W.M., Miller, G.J., Eds.; Educational psychology; Wiley: Hoboken, NJ, USA, 2003; Volume 7, pp. 177-198.

72. Haimovitz, K.; Dweck, C.S. The Origins of Children's Growth and Fixed Mindsets: New Research and a New Proposal. Child Dev. 2017, 88, 1849-1859. [CrossRef] [PubMed]

73. Wiliam, D.; Leahy, S. Embedding Formative Assessment: Practical Techniques for K-12 Classrooms; Learning Sciences International: West Palm Beach, FL, USA, 2015.

74. Boud, D.; Lawson, R.; Thompson, D.G. The Calibration of Student Judgement Through Self-Assessment: Disruptive Effects of Assessment Patterns. High. Educ. Res. Dev. 2014, 34, 45-59. [CrossRef]

75. Jönsson, A.; Prins, F. Editorial: Transparency in Assessment-Exploring the Influence of Explicit Assessment Criteria. Front. Educ. 2019, 3. Available online: https:/ / www.frontiersin.org/articles/10.3389/feduc.2018.00119/full (accessed on 12 June 2021). [CrossRef]

76. Wiggins, G.; McTighe, V. The Understanding by Design Guide to Creating High-Quality Units; ASCD: Alexandria, VA, USA, 2011.

77. Taras, M. Student Self-Assessment: Processes and Consequences. Teach. High. Educ. 2010, 15, 199-209. [CrossRef]

78. Boud, D. Enhancing Learning Through Self-Assessment, 2nd ed.; Routledge Falmer: London, UK; New York, NY, USA, 2013. 